\title{
Changes in the marine-terminating glaciers of central east Greenland, 2000-2010
}

\author{
K. M. Walsh ${ }^{1,2, *}$, I. M. Howat ${ }^{1,2}$, Y. Ahn ${ }^{2, * *}$, and E. M. Enderlin ${ }^{1,2}$ \\ ${ }^{1}$ School of Earth Sciences, The Ohio State University, Columbus, Ohio, USA \\ ${ }^{2}$ Byrd Polar Research Center, The Ohio State University, Columbus, Ohio, USA \\ *now at: NASA GSFC, Greenbelt, Maryland, USA \\ *** now at: the School of Technology, Michigan Technical University, Houghton, Michigan, USA
}

Correspondence to: K. M. Walsh (walsh.327@osu.edu)

Received: 1 August 2011 - Published in The Cryosphere Discuss.: 21 October 2011

Revised: 27 January 2012 - Accepted: 6 February 2012 - Published: 17 February 2012

\begin{abstract}
Marine-terminating outlet glaciers of the Greenland Ice Sheet have undergone substantial changes over the past decade. The synchronicity of these changes suggest a regional external forcing, such as changes in coastal ocean heat transport and/or increased surface melt and subglacial runoff. A distinct contrast in rates of ice front retreat has been observed between glaciers north and south of $69^{\circ} \mathrm{N}$ latitude on along the East Greenland coast. This latitude corresponds with the northward limit of subtropical waters carried by the Irminger Current, suggesting variability in ocean heat transport as the dominant forcing. Glacier surging, however, is yet another mechanism of change in this region. In order to provide further spatial and temporal constraint on glacier change across this important oceanographic transition zone, we construct time series of thinning, retreat and flow speed of 37 marine-terminating glaciers along the central east Greenland coast from 2000 to 2010 . We assess this dataset for spatial and temporal patterns that may elucidate the mechanisms of glacier change. We confirm that glacial retreat, dynamical thinning, and acceleration have been more pronounced south of $69^{\circ} \mathrm{N}$, with a high degree of variability along the Blosseville Coast and little inter-annual change in Scoresby Sound. Our results support the conclusion that variability in coastal ocean heat transport is the primary driver of regional glacier change, but that local factors, such as surging and/or individual glacier morphology, are overprinted on this regional signal.
\end{abstract}

\section{Introduction}

Multiple studies using a range of methods show that the recent increase in the Greenland Ice Sheet's rate of mass loss has been due to both increased surface melting and discharge from fast-flowing, marine-terminating outlet glaciers, predominately along the southeast and northwest coasts (e.g. Krabill et al., 1999, 2004; Tapley et al., 2004; Luthcke et al., 2006; Rignot and Kanagaratnam, 2006; Thomas et al., 2006; Pritchard et al., 2009; Velicogna and Wahr, 2006; Velicogna, 2009; van den Broeke, 2009). Previous studies have attributed retreat and acceleration of these glaciers to changes in ocean (e.g. Holland et al., 2008; Hanna et al., 2009; Straneo et al., 2010) and atmospheric circulation (Box et al., 2006; Zwally et al., 2011). The observed speedup of outlet glaciers in southeast Greenland in the early 2000's coincided with increasing trend in sea surface temperatures in the subpolar North Atlantic Ocean (Bersch et al., 2007; Myers et al., 2007; Thierry et al., 2008; Straneo et al., 2010). Additionally, thinning and retreat of Jakobshavn Isbræ coincided with a sharp increase in subsurface ocean temperatures along Greenland's west coast due to increased influx of warmer water originating in the Irminger Sea from the southeast after 1996 (Holland et al., 2008; Hanna et al., 2009). Similarly, Seale et al., 2011, suggests that increased subtropical water transport onto the East Greenland continental shelf and into glacier fjords may explain retreat, and subsequent stabilization, of glaciers south of $69^{\circ} \mathrm{N}$, as well as the relative stability of glaciers to the north of that latitude.

Instead of, or in addition to, to changes in the surrounding ocean, increased melting of glacier calving faces may 
be linked to an increase in melt water runoff due to recent atmospheric warming (Box et al., 2009; Christofferson et al., 2011). An increase in melt water discharge at the grounding zone would invigorate buoyancy-driven circulation along the front, entraining warmer ocean water and increasing melt rates and, potentially, calving rates through undercutting (Motyka et al., 2003; Rignot et al., 2010). Such an increase in runoff is supported by an observed, ice sheetwide increase in melt season (June-August) surface temperature, averaging $0.8^{\circ} \mathrm{C}$ between 1997 and 2007 (Box et al., 2009). There are, however, no direct observations of increased runoff leading to increase submarine melting. Additionally, many glaciers underwent large-scale retreat in the winter months (e.g. Howat et al., 2008, 2011; Seale et al., 2011), and no simple causality between runoff and front retreat is apparent from the existing data (Luckman et al., 2006; Seale et al., 2011).

Finally, substantial inter-annual changes in these glaciers may be the result of glacier surging. Most of the marineterminating glaciers on Greenland's east coast between Kangerdlugssuaq Glacier $\left(\sim 68^{\circ} \mathrm{N}\right)$ and northern Scoresby Sound $\left(\sim 72^{\circ} \mathrm{N}\right)$ have either shown surging behavior or are expected to be surging glaciers based on their surface morphology (Jiskoot et al., 2003). Both Alaskan-type surging (i.e. surging induced by basal hydrology) and Svalbard-type surging (i.e. surging induced by ice thermodynamics) have been observed in this region (Jiskoot and Juhlin, 2009), with the latter thought to be more prevalent. Alaskan-type surge events are typified by acceleration lasting several months to a year or more, followed by a sudden deceleration and quiescent phase of several decades. In contrast, Svalbardtype events typically have a shorter phase of acceleration and longer phases of deceleration and periods of quiescence lasting centuries (Jiskoot et al., 2001). Unlike climate and oceaninduced change, however, there is no clear reason why the timing of surges should be synchronous between multiple glaciers. Also, whereas dynamic thinning following retreat is due to increased along-flow ice stretching, thinning following a glacier surge occurs due to melting. This results in a distinctly different pattern of thinning; dynamic thinning propagates inland from the front with acceleration while thinning following a surge remains concentrated at low elevations, where mass balance rates are most negative, and is concurrent with deceleration. Patterns of thinning thus far observed for rapidly changing glaciers in the northwest and southeast over the past decade have been associated with retreat and acceleration, and shown a clear inland propagation with accelerations, indicating dynamic thinning (e.g. Howat et al., 2008; McFadden et al., 2011).

One approach for determining which of the possible mechanisms are responsible for recent glacier change in Greenland is to compare spatial and temporal patterns of behavior of a regional sample of glaciers with corresponding patterns in ocean and climate regimes. The East Greenland coast abuts the Denmark Strait, straddling the ocean circulatory and thermodynamic transition zone between the Irminger and Greenland Seas (Fig. 1), providing an ideal study area for this comparative approach. In the above-mentioned study, Seale et al. (2011) examined patterns of front retreat for 32 glaciers in East Greenland between 2000 and 2009 and found a distinct contrast in retreat between those in south, which underwent widespread synchronous retreat followed by stabilization, and those in the north, which remained largely unchanged. The transition between these two regimes, centered at approximately $69^{\circ} \mathrm{N}$, corresponds with the northern extent of warm subtropical waters transported within the Irminger Current. The spatial correlation with this boundary, as well as temporal correlation between glacier variability and variability in heat transport, suggests that retreat was primarily due to a circulatory change associated with this current.

In this study, we add further constraints on the spatial and temporal patterns of glacier change across this important transition zone. From a range of remote sensing data, we construct time series' of front position, surface elevation and flow speeds for all 38 marine-terminating East Greenland glaciers wider than $2 \mathrm{~km}$ between $\sim 65^{\circ} 34^{\prime} \mathrm{N}$ to $\sim 71^{\circ} 53^{\prime} \mathrm{N}$ over the period 2000 and 2010 (Fig. 1). We examine temporal and spatial variability in these records for patterns that may elucidate the mechanisms of change.

\section{Data sources and methods}

Our data sources include (1) visible and near-infrared (VNIR) bands of the Advanced Spaceborne Thermal Emission Reflector and Radiometer (ASTER) and (2) panchromatic band imagery from the Landsat-7 Enhanced Thematic Mapper Plus (Landsat-7 ETM+), both spanning the period 2000 to 2010. Sequences of imagery from both sensors were used to delineate front position and flow speed, and ASTER digital elevation models (DEM) yielded elevation change. More detail regarding these measurements is provided below.

Imagery from Landsat-7 were obtained from the United States Geological Survey (USGS) Global Visualization Viewer (GLOVIS, http://glovis.usgs.gov) public archive. ASTER orthoerectified images and DEMs (ASTDMO product) were obtained from the USGS Land Processes Data Active Archive Center (LP DAAC, https://lpdaac.usgs.gov). Both sensors have a pixel resolution of $15 \mathrm{~m}$ and nominal repeat interval of 16 days, although higher temporal resolution is obtained due to overlap of the Landsat paths and by using both ascending and descending passes. Unlike Landsat, ASTER images are only acquired on-demand, so that few images are available for a given glacier each melt season (Joughin et al., 2008). ASTER DEMs are created using nadir and backward-looking band-3 and $3 \mathrm{~N}$ image pairs acquired 57 seconds apart. Relative DEMs were produced without ground control and were later registered using offsets over off-ice terrain (i.e. stationary bedrock). Following this correction, DEM vertical accuracy is better than $10 \mathrm{~m}$ over glacier ice. 

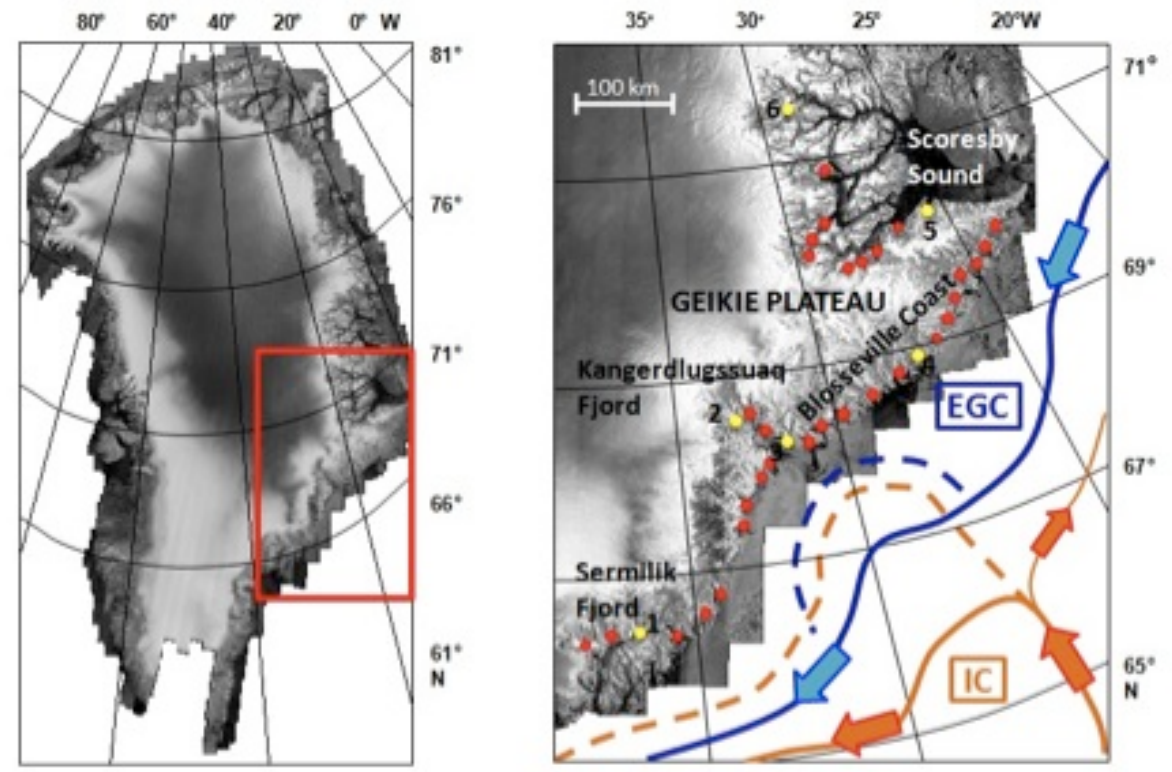

Fig. 1. RADARSAT mosaic showing area of study; including Sermilik Fjord, Kangerdlugssuaq Fjord, Geikie Plateau, Blosseville Coast, and Scoresby Sound with relevant ocean currents in the region of study; red dots indicate each glacier; glaciers discussed in detail in the text are indicated by yellow dots and numerals $(1=$ Midgard; $2=$ Kangerdlugssuaq; 3 = Frederiksborg; $4=$ Sortebrae; $5=$ Sydbrae; $6=$ DaugaardJensen); "IC" and the orange lines depict the Irminger Current; "EGC" and the blue lines depict the East Greenland Current; dotted lines represent variations in each ocean current.

\subsection{Front positions}

We utilized two methods for measuring the changes in glacier front position. In the first method, the entire front is digitized and the change in front position is calculated as the change in area of successive polygons formed by the intersection of the front and a reference polygon, divided by the glacier width (i.e. the "Box Method", e.g. Moon and Joughin, 2008; Howat and Eddy, 2010; McFadden et al., 2011). In the second method, the front position is simply mapped at the intersection of front with the glacier flow line. The first method is less arbitrary because it accounts for asymmetric variations in front shape, but this method is not practical for large numbers of glaciers and images and cannot be used when the front is only partially visible. The centerline method, in contrast, is far less labor intensive and measurements can be made when the front is partially obscured by clouds. This method, however, only captures variability at a single point along the front and therefore may effectively represent change. In order to test the sensitivity of our results to either method, we mapped the fronts of three glaciers using both methods (Midgard, Kangerdlugssuaq, Sortebrae). The two methods yield front position changes that differed, on an average, by $\pm 0.1 \mathrm{~km}$, which is comparable to the measurement error. Further, and more importantly, the temporal variation between the methods is nearly identical. We therefore used the more efficient centerline method to generate our dataset.

\subsection{Surface elevations}

We extracted elevation profiles along flow line transects from each glacier from the ASTER DEMs. Individual elevation profiles were manually edited for errors resulting from clouds and spurious elevations resulting from failure of the DEM generation software. The data were then vertically registered by subtracting offsets over ice-free terrain. Multiple elevations for a given year were averaged together to give a single elevation profile for each year in the time series.

\subsection{Surface speeds}

We extracted glacier surface speeds from ASTER and Landsat image pairs collected between 10-90 days apart using the IMMATCH/MIMC Repeat Image Feature Tracking (RIFT) software distributed by the Glacier Dynamics Group at The Ohio State University. A detailed description of the software, including a full error assessment and validation, is given in Ahn and Howat (2011). Here we examine a time series of average surface speeds taken from a point along the central flow line approximately $10 \mathrm{~km}$ from the most retreated front position of each glacier. Error in this method varies with time between image pairs, and are less than $1 \mathrm{~m} \mathrm{~d}^{-1}$ for the data used in this study (Ahn and Howat, 2011). 
Table 1. Each study glacier, listed by latitude, with terminus retreat, surface elevation change, average speed, and change in surface speed (positive values indicate acceleration; negative values indicate deceleration) at a point $15 \mathrm{~km}$ from each glacier's most retreated terminus over the 2000-2010.

\begin{tabular}{|c|c|c|c|c|c|}
\hline Latitude (deg) & Glacier Name & Max. Terminus Retreat $(\mathrm{km})$ & Thinning 15 km Upglacier (m) & Average Sfc. Speed $\left(\mathrm{m} \mathrm{d}^{-1}\right)$ & Change in Sfc. Speed $\left(\mathrm{m} \mathrm{d}^{-1}\right)$ \\
\hline 66.3 & Helheim & 7.8 & no data & 15.4 & 8.8 \\
\hline 66.38 & Fenris & 1,6 & 3 & 3,6 & -2.7 \\
\hline 66.45 & Midgard & 7.7 & 62 & 6.8 & 9.4 \\
\hline 66.48 & Midgard Nord & 1.0 & 33 & 1.0 & -0.7 \\
\hline 66.57 & Steenstrup & 0.9 & 5 & 2.3 & 0.8 \\
\hline 66.78 & Tasiliaq & 1.5 & 19 & 5.0 & -1.3 \\
\hline 67.25 & Kruuse & 3.1 & 46 & 2.9 & -3.9 \\
\hline 67.45 & Nordre & 3.4 & 42 & no data & no data \\
\hline 67.88 & Polaric 2 & 1.5 & no data & 1.9 & -0.4 \\
\hline 67.97 & Polaric 1 & 0.4 & 17 & 3.9 & 1.0 \\
\hline 68.28 & Frederiksborg & 1.4 & no data & 4.2 & -3.0 \\
\hline 68.33 & Sorgenfri & 0.3 & no data & 1.2 & -1.9 \\
\hline 68.4 & Christian IV & 0.3 & 31 & 4.3 & 0.0 \\
\hline 68.41 & Nordfjord & 0.2 & 18 & 0.3 & 0.3 \\
\hline 68.5 & Rosenborg & 1.7 & no data & 1.2 & 2.4 \\
\hline 68.53 & Courtauld & 0.4 & 12 & no data & no data \\
\hline 68.57 & Kronborg & 2.1 & no data & 4.4 & -3.9 \\
\hline 68.63 & Borggraven & 1.4 & 16 & 3.1 & -1.3 \\
\hline 68.63 & Kangerdlugssuaq & 6.3 & 156 & 13.7 & 13.5 \\
\hline 68.73 & Sortebrae & 5.2 & 43 & 0.6 & -0.2 \\
\hline 68.78 & Johan Petersen & 1.2 & no data & 0.0 & 0.0 \\
\hline 68.88 & Storbrae & 1.8 & 27 & 1.4 & 0.0 \\
\hline 68.98 & De Reste Bugt & 1.0 & 41 & 1.7 & 2.8 \\
\hline 69.25 & Barclay Bugt & 1.1 & 31 & 0.6 & -2.4 \\
\hline 69.32 & Dendrit & 0.6 & 17 & 1.9 & 2.8 \\
\hline 69.63 & Bartholinsbrae & 0.9 & 10 & 0.2 & 0.2 \\
\hline 69.87 & Steno Brae & 0.4 & 15 & 0.1 & 0.0 \\
\hline 69.95 & West Krista Dan & 0.8 & -7 & 1.7 & 0.3 \\
\hline 69.96 & Krista Dan & 0.4 & 6 & 0.8 & 0.0 \\
\hline 69.97 & Magga Dan & 0.1 & 7 & 5.9 & -1.8 \\
\hline 70.17 & Sydbrae & 0.4 & 22 & 2.1 & 4.4 \\
\hline 70.27 & Bredegletscher & 1.2 & 36 & 3.7 & -0.8 \\
\hline 70.37 & Vestifjord & 1.8 & no data & 5.3 & -0.7 \\
\hline 70.47 & Dodebrae & 0.2 & 11 & 0.2 & 0.0 \\
\hline 70.6 & Rolige Brae & 0.9 & 9 & 2.0 & -3.4 \\
\hline 71.17 & Eilson & 0.2 & 10 & 0.3 & -1.4 \\
\hline 71.9 & Daugaard-Jensen & 1.4 & 3 & 9.5 & 6.0 \\
\hline
\end{tabular}

\section{Results}

We find a wide range in glacier behavior across our study area over the past decade. In general, our results corroborate the findings of Seale et al. (2011) of a contrast in interannual glacier behavior north and south of $69^{\circ} \mathrm{N}$. A greater magnitude of change, especially in magnitude of front retreat, occurred on and to the south of the Blosseville Coast. In contrast, we find little change occurred on the glaciers on the northern portion of the Geikie Plateau and Scoresby Sound. Table 1 summarizes terminus retreat, surface elevation change and average surface speed for each glacier. We first summarize the results for each observed parameter and then provide more detail by sub-region.

\subsection{Overview of front position changes}

All 37 glaciers retreated between 2000 and 2010, but the magnitude of retreat was highly variable, ranging from $\leq 0.1 \mathrm{~km}$ to $9 \mathrm{~km}$ (Fig. 2). The mean retreat for all 37 glaciers over the time period was $1.6 \mathrm{~km}$, with the largest change observed to be $9.2 \mathrm{~km}$ from 2000 to 2010 (Midgard Glacier). Greater front retreat is found from Sermilik Fjord to the Blosseville Coast, with 14 of the 25 glaciers in this area retreating $>1.0 \mathrm{~km}$ over the time period. The mean total retreat of glaciers in this region of the study area was $2.1 \mathrm{~km}$, while the mean total retreat of glaciers terminating into Scoresby Sound and Gasefjord (inner Scoresby Sound) and further north was $<0.5 \mathrm{~km}$. The large retreats of a few glaciers, however, skew the mean front retreat; the median retreat for all 37 glaciers in the study area was $0.9 \mathrm{~km}$. Nearly half of the glaciers retreated $1.0 \mathrm{~km}$ or more during the time period.

\subsection{Overview of surface elevation changes}

Surface elevation changes were much more variable and not as spatially consistent as changes in front position. We observe generally no change on the glaciers terminating into Scoresby Sound and its channels north of the eastern-most 


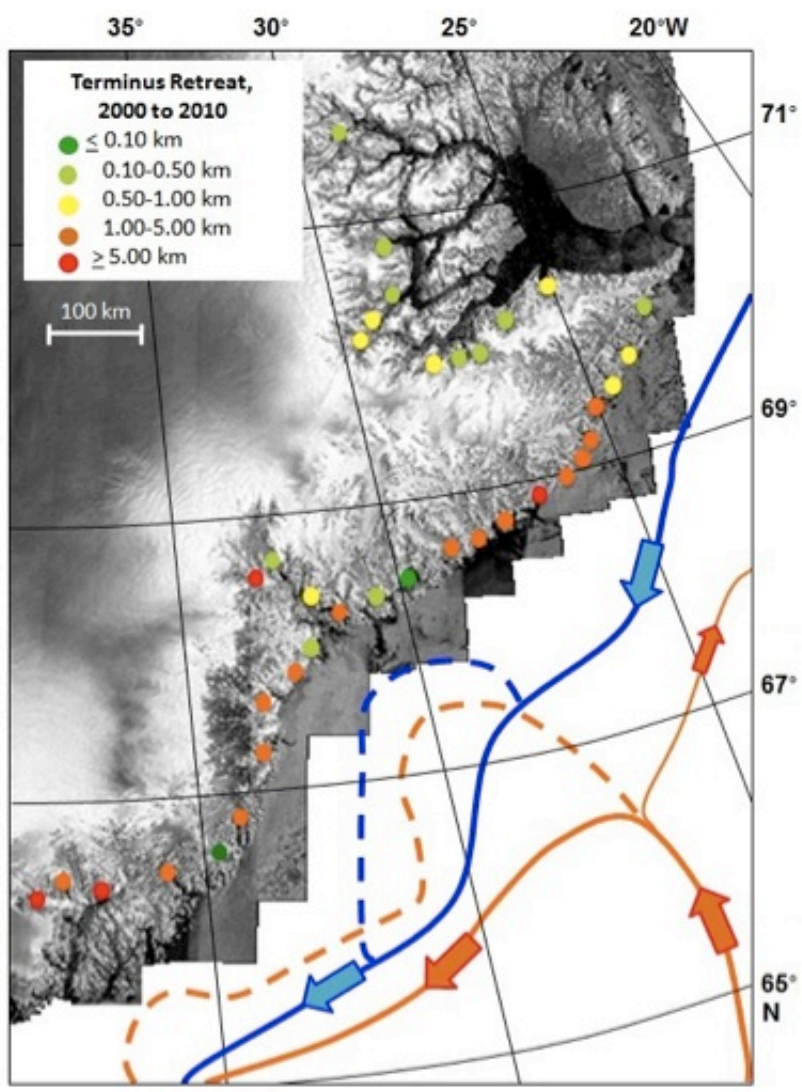

Fig. 2. Change in front position (2000-2010) for all marineterminating outlet glaciers in this analysis. Circles indicate the location of each glacier and colors indicate magnitude of retreat.

point of the Geikie Plateau peninsula $\left(70^{\circ} 9^{\prime} \mathrm{N}, 22^{\circ} 3^{\prime} \mathrm{W}\right)$ (Fig. 3). For glaciers south of $70^{\circ} 9^{\prime} \mathrm{N}$, rates of thinning $15 \mathrm{~km}$ inland of the front varied from $\geq 10 \mathrm{~m}$ of thinning to roughly $155 \mathrm{~m}$ of thinning between 2000 and 2010 . For glaciers north of $70^{\circ} 9^{\prime} \mathrm{N}$, thinning rates varied from approximately $10 \mathrm{~m}$ of thickening to $35 \mathrm{~m}$ of thinning between 2000 and 2010. Only two glaciers thickened, on the order of 5-7 m, both of which were located north of $70^{\circ} 9^{\prime} \mathrm{N}$. Figure 5 shows elevation profiles for 7 glaciers in this data set.

\subsection{Overview of surface speed changes}

Surface speeds varied both spatially and temporally, with the highest speeds measured on Kangerdlugssuaq and Helheim glaciers during periods of acceleration between 2005 and 2006 (Fig. 4) (e.g. Howat et al., 2008a; Joughin et al., 2008; Luckman et al., 2006). Many of the glaciers in this study exhibit seasonal variability in surface speed, oscillating on the order of $\pm 7 \mathrm{~m}$ per year, especially in the Scoresby Sound region north of the Geikie Plateau. For example, DaugaardJensen Gletscher had speeds varying annually by $25 \%$ (between 7.5 and $11 \mathrm{md}^{-1}$ ), while Rolige Brae had surface

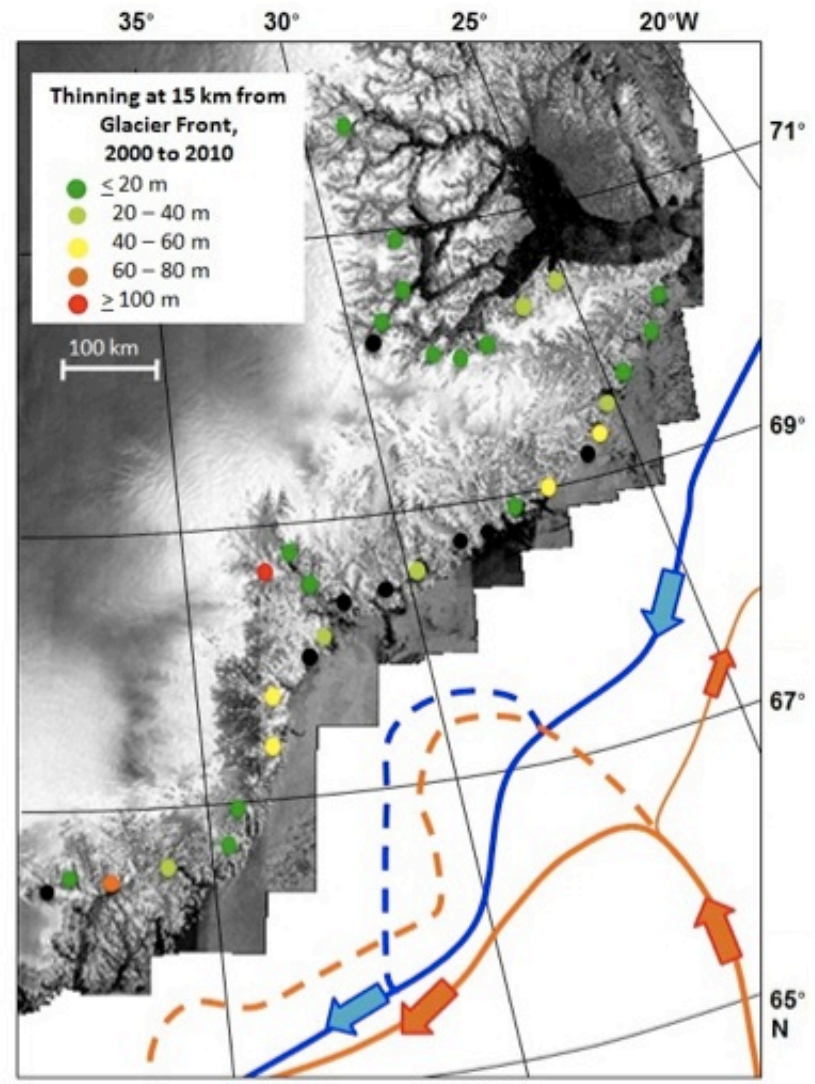

Fig. 3. Change in surface elevation (all values negative) (20002010) for all marine-terminating outlet glaciers in this analysis. Thinning measured at $15 \mathrm{~km}$ from most retreated front position. Circles indicate the location of each glacier and colors indicate magnitude of thinning (black circles indicate no data available).

speeds varying seasonally between $6 \mathrm{md}^{-1}$ in the summer to near stagnation in the winter. Kangerdlugssuaq Glacier displayed the largest range in its surface speed as a result of its sustained acceleration between 2004 and 2006, accelerating from $10 \mathrm{~m} \mathrm{~d}^{-1}$ to $27 \mathrm{~m} \mathrm{~d}^{-1}$. Maximum surface speeds occurred in the summer for all glaciers, with a mean maximum summer surface speed of $7.5 \mathrm{~m} \mathrm{~d}^{-1}$ for all glaciers in the study.

\subsection{Spatial patterns of glacier change}

Here we discuss differences in glacier change between the three major sub-regions of the study area, with several glaciers discussed in detail to highlight regionally representative behavior. The regions are presented from south to north.

\subsubsection{Sermilik Fjord to Kangerdlugssuaq Fjord}

This area underwent the greatest magnitude of change in dynamics (i.e. front retreat, thinning, surface speed), particularly in the magnitude of front retreat. Unlike glaciers 


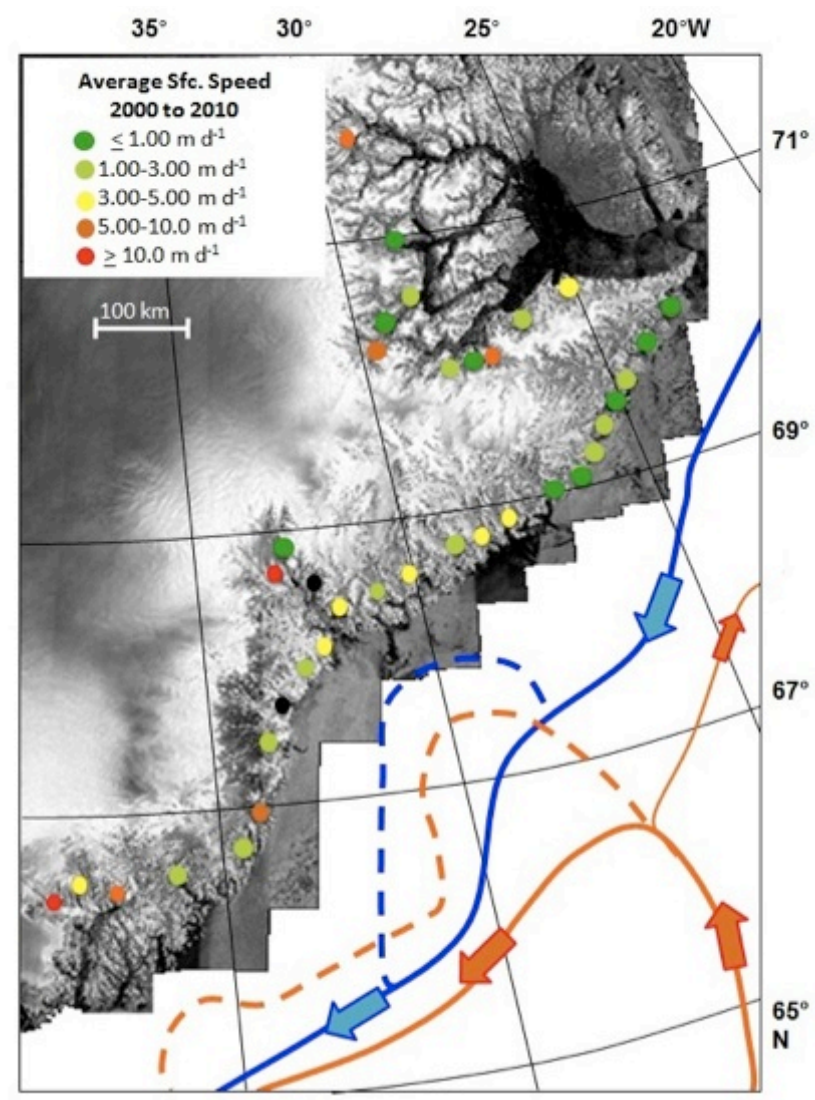

Fig. 4. Average surface speeds (in $\mathrm{md}^{-1}$ ) for all marineterminating glaciers in the data set. Circles indicate the location of each glacier and colors indicate magnitude of glacier speed (black circle indicates no data available).

draining the Geikie Plateau to the north, these drain directly from the central Greenland Ice Sheet. Peak rates of front change occurred between 2003 and 2005, suggesting a regional forcing that was at a maximum during this time. The mean front retreat of glaciers in this subset was $2.9 \mathrm{~km}$, and the median front retreat was $1.6 \mathrm{~km}$. The average thinning observed $15 \mathrm{~km}$ inland of the glacier terminus was $28 \mathrm{~m}$, and the elevation profiles (Fig. 5) for roughly half of these glaciers show evidence of extensive thinning (i.e. mean thinning at $15 \mathrm{~km}$ from the glacier terminus $>30 \mathrm{~m}$ ). The mean maximum surface speed was $8.8 \mathrm{~m} \mathrm{~d}^{-1}$, with a median maximum surface speed of $7.7 \mathrm{~m} \mathrm{~d}^{-1}$. All maximum surface speeds occurred in the summer months.

Midgard Glacier, which terminates into the northeast channel of Sermilik Fjord, underwent the largest magnitude of change in front position, thinning, and surface speed of the glaciers sampled (Fig. 6). The rate of inter-annual retreat of Midgard increased in 2003, with a pronounced pattern of seasonal advance-and-retreat lasting through 2007. Between early 2008 and late 2009 , the glacier retreated $4.0 \mathrm{~km}$ before a brief period of re-advance in late 2009/early 2010

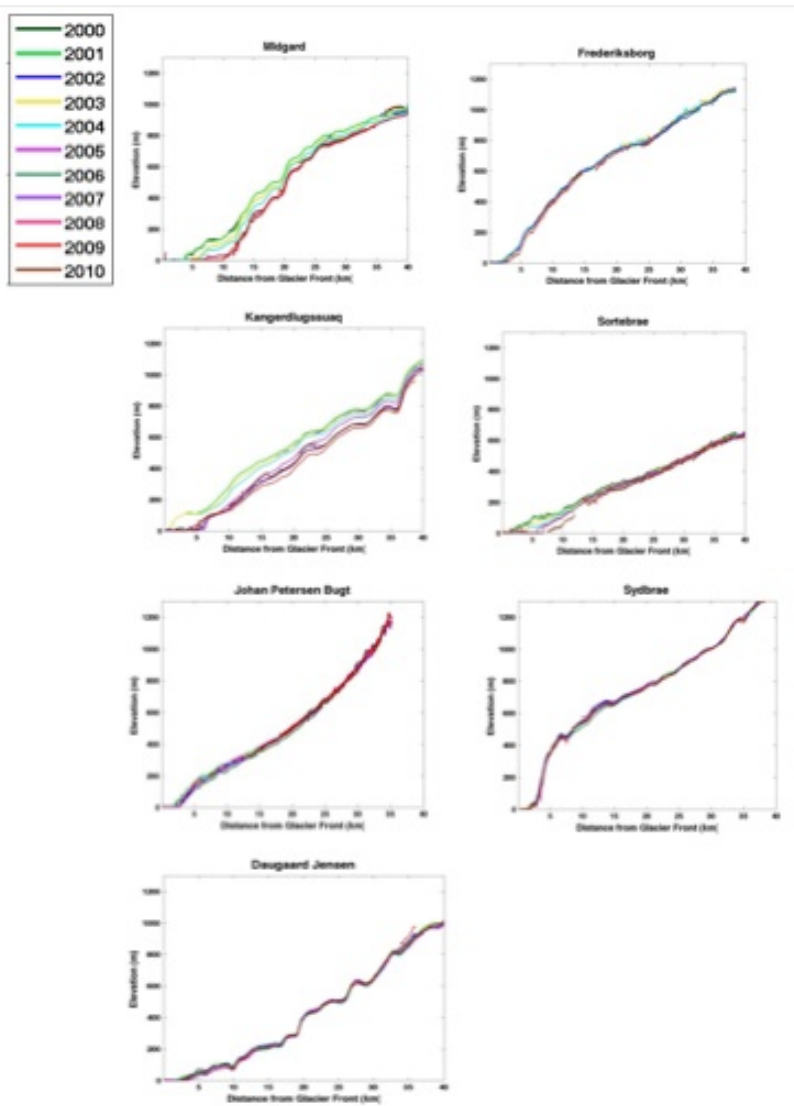

Fig. 5. Elevation profiles for seven (7) marine-terminating outlet glaciers in the dataset. Latitude increases from top to bottom, starting with Midgard Glacier $\left(66^{\circ} 26^{\prime} \mathrm{N}, 36^{\circ} 45^{\prime} \mathrm{W}\right)$ to Daugaard Jensen Glacier $\left(71^{\circ} 54^{\prime} \mathrm{N}, 28^{\circ} 36^{\prime} \mathrm{W}\right)$. Elevation profiles show annual average elevation from the terminus upglacier to the accumulation zone for each glacier.

and an additional retreat of $1.5 \mathrm{~km}$. The most significant thinning occurred below $1000 \mathrm{~m}$ a.s.l. and within $40 \mathrm{~km}$ of the terminus; the glacier thinned roughly $100 \mathrm{~m}$ from 2000 to 2010 at $10 \mathrm{~km}$ from the terminus, decreasing up-glacier. This rate of thinning was consistent with the pattern of front retreat throughout the time series, with an overall acceleration in both front retreat and thinning occurring in late 2007 into 2008. Surface speeds increased from roughly $4 \mathrm{~m} \mathrm{~d}^{-1}$ in 2000 to $9 \mathrm{~m} \mathrm{~d}^{-1}$ in 2009 at a center point roughly $5 \mathrm{~km}$ up-glacier from the glacier's most retreated position.

\subsubsection{Blosseville Coast}

The glaciers along the Blosseville Coast display the highest degree of spatiotemporal variability in changes in front position, thinning, and surface speed. While most glaciers underwent substantial change, there was no clear temporal or spatial pattern. On average, glaciers in this region retreated by $1.6 \mathrm{~km}$, with a median retreat of $0.9 \mathrm{~km}$ and a median thinning of $22 \mathrm{~m}$. Thinning rates were highly variable, 


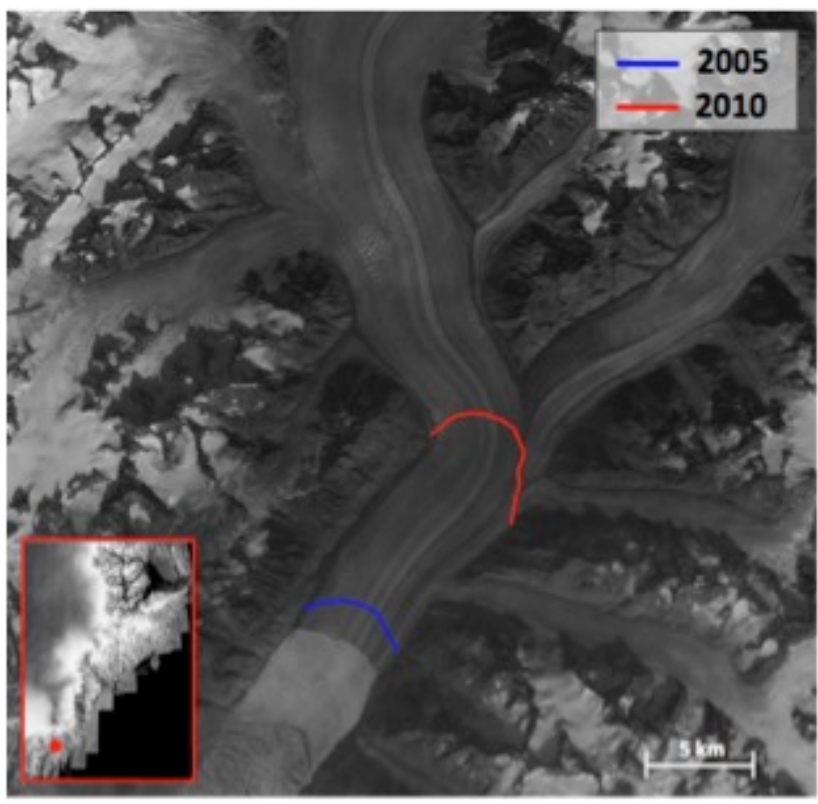

Fig. 6. Landsat-7 ETM+ image from 2000 showing progression of retreat in 2005 and 2010 at Midgard; the glacier has retreated roughly $9 \mathrm{~km}$ since 2000 .

with dynamic thinning (as identified by rapid acceleration followed by extensive thinning and stretching originating at the front) evident on 2 of the 14 glaciers in this area. The greatest thinning was observed at Kangerdlugssuaq $(160 \mathrm{~m})$. The mean (median) maximum surface speed was $7.4 \mathrm{~m} \mathrm{~d}^{-1}$ $\left(5.9 \mathrm{~m} \mathrm{~d}^{-1}\right)$. All maximum surface speeds occurred in June or July.

Kangerdlugssuaq and Frederiksborg are examples of two glaciers in close proximity to one another that display contrasting behavior. Kangerdlugssuaq is $\sim 9 \mathrm{~km}$ wide and terminates into a $40 \mathrm{~km}$ long fjord (Fig. 7). Several studies have documented its large, inter-annual retreat, acceleration and thinning (e.g. Luckman et al., 2006; Howat et al., 2007, 2011). This glacier's front oscillated seasonally by almost $2 \mathrm{~km}$ between 2000 and 2004. Between late 2004 and early 2006, Kangerdlugssuaq retreated roughly $5 \mathrm{~km}$. During retreat, the glacier accelerated from roughly $12 \mathrm{~m} \mathrm{~d}^{-1}$ in 2000 to $27 \mathrm{~m} \mathrm{~d}^{-1}$ in 2006 and thinned more than $150 \mathrm{~m}$ near the front. Thinning propagated up-glacier following the period of acceleration. Kangerdlugssuaq's surface speeds slowed following the 2005-2006 acceleration, and the glacier readvanced to approximately $7 \mathrm{~km}$ from its position in 2000 .

Frederiksborg is a much narrower glacier, terminating into the same fjord as Kangerdlugssuaq at two calving fronts separated by a nunatak. Frederiksborg retreated roughly $1.5 \mathrm{~km}$ from 2000 to 2004, and has maintained a steady pattern of a $0.7 \mathrm{~km}$ seasonal oscillation since 2005. This glacier had negligible elevation change over the study period and surface speeds were relatively stable from 2000 to 2006, varying between 3 and $5 \mathrm{md}^{-1}$, with no observed seasonality.

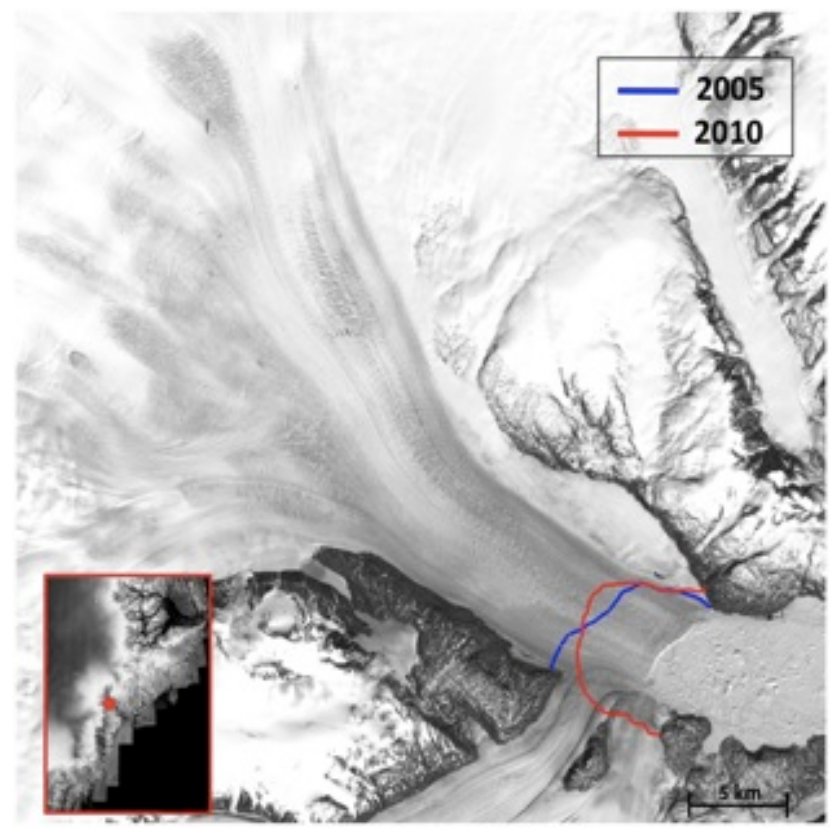

Fig. 7. Landsat-7 ETM+ image from 2000 showing progression of retreat in 2005 and 2010 at Kangerdlugssuaq; the glacier has retreated roughly $7 \mathrm{~km}$ since 2000

Beginning in 2007, however, the glacier began to show a large seasonal cycle in speed, from near stagnation in the winter to $13 \mathrm{~m} \mathrm{~d}^{-1}$ in mid-summer, coinciding with the large seasonal variation in front position. Several glaciers in this region have been previously identified as surging glaciers, and two examples of surging behavior are evident in this study: Sortebrae and Johan Petersen. Sortebrae $\left(68^{\circ} 44^{\prime} \mathrm{N}\right.$, $26^{\circ} 59^{\prime} \mathrm{W}$ ) surged in the mid 1990's (e.g. Jiskoot et al., 2001; Jiskoot and Juhlin, 2009) and retreated steadily at roughly $500 \mathrm{~m} \mathrm{yr}^{-1}$ from 2000 to 2010 . Consistent with this steady retreat, the glacier thinned $60 \mathrm{~m}$ within $15 \mathrm{~km}$ of its front with no resolvable thinning above. Since this glacier is in a quiescent period of surge behavior (Jiskoot et al., 2001; Murray et al., 2002) surface speeds were relatively slow, ranging from near stagnation to $3 \mathrm{~m} \mathrm{~d}^{-1}$, with slight seasonality. Johan Petersen $\left(68^{\circ} 47^{\prime} \mathrm{N}, 26^{\circ} 23^{\prime} \mathrm{W}\right)$, directly east of Sortebrae, retreated steadily at roughly $120 \mathrm{~m} \mathrm{yr}^{-1}$ from 2000 to 2010 , which may be evidence that the glacier is in the quiescent phase of a surge cycle. The glacier thinned roughly $20 \mathrm{~m}$ within $15 \mathrm{~km}$ of its most retreated terminus position between 2000 and 2006, with no elevation data available at this point for 2007 through 2010. Surface speeds for this glacier were very low, and ranged from stagnation to less than $0.5 \mathrm{~m} \mathrm{~d}^{-1}$, with no seasonality evident. Additionally, previous studies have identified Dendrit $\left(69^{\circ} 18^{\prime} \mathrm{N}\right.$, $\left.25^{\circ} 10^{\prime} \mathrm{W}\right)$ and Borggraven $\left(68^{\circ} 36^{\prime} \mathrm{N}, 28^{\circ} 4^{\prime} \mathrm{W}\right)$ glaciers as probable surging glaciers, but we find no resolvable change in surface elevation to support this. 


\subsubsection{Scoresby Sound}

The glaciers terminating into and north of Scoresby Sound exhibited relatively little change in front position, thinning, and surface speed. The mean (median) front retreat of glaciers in this subset was $0.5 \mathrm{~km}(0.3 \mathrm{~km})$ with strong seasonal variations in front position and speed. The mean (median) maximum surface speed was $6.6 \mathrm{~m} \mathrm{~d}^{-1}\left(5.3 \mathrm{~m} \mathrm{~d}^{-1}\right.$ at Vestifjord Glacier). Daugaard-Jensen Gletscher showed the greatest seasonal amplitude in front position $(\sim 1 \mathrm{~km})$, while its inter-annual mean front position, however, has not changed since 2000. The glacier thinned approximately $30 \mathrm{~m}$ below $400 \mathrm{~m}$ elevation, with negligible thinning at higher elevations. Daugaard-Jensen Gletscher is also the fastest moving glacier observed in the Scoresby Sound region, with a maximum speed of $11 \mathrm{~m} \mathrm{~d}^{-1}$ in June 2006 and a strong seasonal pattern of acceleration and deceleration mimicking the cyclic pattern of front advance and retreat.

\section{Discussion}

Changes in the front positions, surface elevations, and surface speeds of 37 marine-terminating glaciers in central east Greenland indicate that, consistent with the results of Seale et al. (2011), glaciers south of the Blosseville Coast thinned and retreated more extensively than glaciers terminating into the Scoresby Sound to the north. Additionally, we identify dynamic thinning of roughly half of the glaciers between Sermilik and Kangerdlugssuaq fjords, with the most dramatic examples being Helheim, Kangerdlugssuaq and Midgard Glaciers. Dynamic thinning is mostly confined to the south of Kangerdlugssuaq Glacier, where mean and median surface speeds are the highest.

The ten outlet glaciers on the coast from Sermilik Fjord to Kangerdlugssuaq fjords all underwent accelerated retreat following 2003, a year of anomalously high air and sea surface temperatures along the southeast Greenland coast (Howat et al., 2008a). Consistent with a loss in flow resistance due to this retreat; these glaciers underwent acceleration and thinning. In contrast, glaciers of Blosseville Coast displayed a high spatial variability, possibly linked to surge behavior, while glaciers of Scorebsy Sound displayed little change. As pointed out by Seale et al. (2011), increases in surface air temperature were similar over the East Greenland coast, so the latitudinal pattern does not appear to be directly linked to atmospheric warming. Instead, oceanographic reanalysis model output from the NEMO ocean model, the OPA9 ocean model, and the LIM2.0 sea ice model used in the study by Seale et al. (2011) show a distinct warming of deep coastal waters south of $69^{\circ} \mathrm{N}$ between 1996 and 2004, followed by cooling until 2008, which is consistent with observed glacier front variability; refer to Seale et al. (2011) and references therein for more details concerning this ocean model reanalysis. In contrast, and consistent with little glacier change there, ocean waters north of $69^{\circ} \mathrm{N}$ showed much smaller variability and rarely exceed $0{ }^{\circ} \mathrm{C}$. Warming below $69^{\circ} \mathrm{N}$ is attributed to increased transport of subtropical water within the Irminger Current. This leads to the conclusion that the dominant forcing of regional-scale spatial variability in glacier behavior is variability in ocean heat transport.

While there is a clear latitudinal contrast in the magnitudes of change, the relative magnitudes of thinning and retreat varied substantially from glacier to glacier. These differences could be the result of differences in glacier geometry, such as gradients in width and ice thickness near the ice front (McFadden et al., 2011). This may be the explanation for differences in behavior between, for example, Kangerdlugssuaq and the neighboring, much narrower, Frederiksborg. Differences amongst glaciers in the northern half of our study area may be linked to glacier surging. Active surge behavior, however, has only be observed at one marine-terminating glacier in the study region; Sortebrae $\left(68^{\circ} 44^{\prime} \mathrm{N}, 26^{\circ} 59^{\prime} \mathrm{W}\right)$, which surged for roughly 19-35 months from 1992 to 1995 following a quiescent phase of between 39-49 years (Jiskoot et al., 2003; Murray et al., 2002). Other studies (e.g. Weidick, 1988; Jiskoot et al., 2003; Jiskoot and Juhlin, 2009) have identified morphological signs of Svalbard-type surging on other glaciers in this region, including Dendrit and Borggraven glaciers along the Blosseville Coast. Beyond the rapid post-surge thinning of Sortebrae and sustained retreat of Johan Petersen Bugt, we find no additional evidence for surge behavior in our dataset. As suggested by Jiskoot and Juhlin (2009) this lack of active surging may reflect the long, century-scale quiescent phase of Svalbard-type surging glaciers. If so, Sortebrae's Alaskan-type surging is anomalous, possibly reflecting some unique condition of basal topography and hydrology. Regardless, such local variability appears to overprint upon the larger, ocean-forced regional pattern of change.

\section{Conclusions}

Our analysis of changes in 37 marine-terminating glaciers between Sermilik Fjord and Scoresby Sound on Greenland's central east coast over the past decade confirm widespread retreat and acceleration on glaciers below $69^{\circ} \mathrm{N}$, with little inter-annual change to the north. This pattern supports the conclusions of Seale et al., 2011 that accelerated melting and calving of glacier fronts in southeast Greenland is linked to changes in coastal ocean heat transport associated with variability in the Irminger Current. While glacier behavior south of Kangerdlugssuaq Glacier was relatively uniform, we find a higher degree of variability between glaciers of the Blosseville Coast that could be the result of a greater influence of individual glacier morphology over external forcing and/or surge behavior.

While this analysis suggests that oceanographic forcing is the dominant control on glacier change south of $69^{\circ} \mathrm{N}$, 
observations of glaciers in this region and of the surrounding ocean are still too limited to state definitively that changing ocean dynamics are the sole regional forcing affecting glacier change in this region. To conclusively test this hypothesis, more information is needed about changes in the subsurface oceanographic conditions along the continental shelf and, especially, closer to outlet glacier termini.

The methods used in this study to quantify glacier change in central east Greenland can be applied to other areas where outlet glaciers are being assessed for ongoing changes in front position, surface elevation, and surface speed. However, the methods and imagery used in this analysis have limitations. The east Greenland coast is often obscured with clouds for much of the year, making it difficult to have a complete time series of Landsat-7 ETM+ or ASTER imagery over a particular location. Future studies should incorporate all-weather and all-year synthetic aperture radar data and high-resolution commercial satellite imagery to provide a much more complete picture of change. Additionally, elevation data collected by airborne laser altimetry acquired as part of NASA's Operation IceBridge initiative will provide a sufficient alternative to using moderate resolution ASTER digital elevation models for measuring changes in glacier surface elevation.

Acknowledgements. This work was made possible by NASA grant NNX08AQ83G, awarded to I. Howat. The RADARSAT image in Figs. 1 through 4 was provided by I. Joughin.

Edited by: J. L. Bamber

\section{References}

Abdalati, W., Krabill, W., Frederick, E., Manizade, S., Martin, C., Sonntag, J., Swift, R., Thomas, R., Wright, W., and Yungel, J.: Outlet glacier and margin elevation changes: Near-coastal thinning of the Greenland ice sheet, J. Geophys. Res., 106, 729-733, 2001.

Ahn, Y. and Howat, I.: Efficient, Automated Glacier Surface Velocity Measurement from Repeat Images Using Multi-Image/MultiChip (MIMC) and Null Exclusion Feature Tracking, IEEE Trans. on Geoscience and Remote Sensing, 2011.

Bersch, M., Yashayaev, I., and Koltermann, K. P.: Recent changes of the thermohaline circulation in the Subpolar North Atlantic, Ocean Dyn., 57, 223-235, 2007.

Box, J., Bromwich, D., Veenhuis, B., Bai, L., Stroeve, J., Rogers, J., Steffen, K., Haran, T., and Wang, S.: Greenland Ice Sheet Surface Mass Balance Variability (1988-2004) from Calibrated Polar MM5 Output, J. Clim., 19, 2873-2800, 2006.

Box, J., Yang, L., Bromwich, D., and Bai, L.: Greenland Ice Sheet Surface Air Temperature Variability: 1840-2007, J. Climate, 22, 4029-4049, 2009.

Christoffersen, P., Mugford, R. I., Heywood, K. J., Joughin, I., Dowdeswell, J. A., Syvitski, J. P. M., Luckman, A., and Benham, T. J.: Warming of waters in an East Greenland fjord prior to glacier retreat: mechanisms and connection to large-scale atmo- spheric conditions, The Cryosphere, 5, 701-714, doi:10.5194/tc5-701-2011, 2011.

Hanna, E., Cappelen, J., Fettweis, X., Huybrechts, P., Luckman, A., and Ribergaard, M. H.: Hydrologic response of the Greenland ice sheet: the role of oceanographic warming, Hydrol. Process., 23, 7-30, 2009.

Holland, D., Thomas, R., De Young, B., Ribergaard, M. H., and Lyberth, B.: Acceleration of Jakobshavn Isbrae triggered by warm subsurface ocean water, Nature Geosci., 1, 659-664, 2008.

Howat, I. and Eddy, A.: Multidecadal retreat of Greenland's marine-terminating glaciers, J. Glaciol., 203, 389-396, 2010.

Howat, I., Joughin, I., and Scambos, T.: Rapid Changes in Ice Discharge from Greenland Outlet Glaciers, Science, 315, 1559, 2007.

Howat, I., Joughin, I., Fahnestock, M., Smith, B., and Scambos, T.: Synchronous retreat and acceleration of southeast Greenland outlet glaciers 2000-2006: ice dynamics and coupling to climate, J. Glac., 54, 646-660, 2008a.

Howat, I., Smith, B., Joughin, I., and Scambos, T.: Rates of southeast Greenland ice volume loss from combined IceSAT and ASTER observations, Geophys. Res. Lett., 35, L17505, doi:10.1029/2008GL034496, 2008b.

Howat, I., Box, J. E., Ahn, Y., Herrington, A., and McFadden, E. M.: Seasonal variability in the dynamics of marine-terminating outlet glaciers in Greenland, J. Glac., 56, 601-613, 2010.

Howat, I., Ahn, Y., Joughin, I., van den Broeke, M., Lenaerts, J., and Smith, B.: Mass balance of Greenland's three largest outlet glaciers, 2000-2010, Geophys. Res. Lett., 38, L12501, doi:10.1029/2011GL047565, 2011.

Jiskoot, H. and Juhlin, D.: Surge of a small East Greenland glacier, 2001-2007, suggest Svalbard-type surge mechanism, J. Glaciol., 55, 567-570, 2009.

Jiskoot, H., Pedersen, A. K., and Murray, T.: Multi-model photogrammetric analysis of the 1990s surge of Sortebrae, East Greenland, J. Glaciol., 47, 677-687, 2001.

Jiskoot, H., Murray, T., and Luckman, A.: Surge potential and drainage-basin characteristics in East Greenland, Ann. Glac., 36, 2003.

Joughin, I., Howat, I., Alley, R. B., Ekstrom, G., Fahnestock, M., Moon, T., Nettles, M., Truffer, M., and Tsai, V. C.: Icefront variation and tidewater behavior on Helheim and Kangerdlugssuaq Glaciers, Greenland, J. Geophys. Res., 113, F01004, doi:10.1029/2007JF000837, 2008.

Joughin, I., Smith, B., Howat, I., Scambos, T., and Moon, T.: Greenland flow variability from ice-sheet-wide velocity mapping, J. Glac., 56, 415-429, 2010.

Krabill, W., Frederick, E., Manizade, S., Martin, C., Sonntag, J., Swift, R., Thomas, R., Wright, W., and Yungel, J.: Rapid Thinning of Parts of the Southern Greenland Ice Sheet, Science, 283, 1522-1524, 1999.

Krabill, W., Hanna, E., Huybrechts, P., Abdalati, W., Cappelen, J., Csatho, B., Frederick, E., Manizade, S., Martin, C., Sonntag, J., Swift, R., Thomas, R., and Yungel, J.: Greenland Ice Sheet: Increased coastal thinning, Geophys. Res. Lett., 31, L24402, doi:10.1029/2004GL021533, 2004.

Luckman, A., Murray, T., de Lange, R., and Hanna, E.: Rapid and synchronous ice-dymanic changes in East Greenland, Geophys. Res. Lett., 33, L035035, doi:10.1029/2005GL025428, 2006.

Luthcke, S., Zwally, H. J., Abdalati, W., Rowlands, D. D., Ray, R. 
D., Nerem, R. S., Lemoine, F. G., McCarthy, J. J., and Chinn, D. S.: Recent Greenland mass loss by drainage system from satellite gravity observations, Science, 314, 1286-1289, 2006.

McFadden, E., Howat, I., Joughin, I., Smith, B., and Ahn, Y.: Changes in the dynamics of marine terminating outlet glaciers in west Greenland (2000-2009), J. Geophys. Res., 116, F02022, doi:10.1029/2010JF001757, 2011.

Moon, T. and Joughin, I.: Changes in ice front position on Greenland's outlet glaciers from 1992 to 2007, J. Geophys. Res., 113, F02022, doi:10.1029/2007JF000927, 2008.

Motyka, R., Truffer, M., Fahnestock, M., Mortensen, J., Rysgaard, S., and Howat, I.: Submarine melting of the 1985 Jakobshavn Isbrae floating tongue and the triggering of the current retreat, J. Geophys. Res., 116, F01007, doi:10.1029/2009JF001632, 2011.

Murray, T., Strozzi, T., Luckman, A., Pritchard, H., and Jiskoot, H. L.: Ice dynamics during a surge of Sortebrae, East Greenland, Ann. Glac., 34, 323-329, 2002.

Myers, P., Kulan, N., and Ribergaard, M. H.: Irminger Water variability in the West Greenland Current, Geophys. Res. Lett., 34, L17601, doi:10.1029/2007GL030419, 2007.

Pritchard, H., Arthern, R., Vaughan, D., and Edwards, L.: Extensive dynamic thinning on the margins of the Greenland and Antarctic ice sheets, Nature, 461, 971-975, 2009.

Rignot, E. and Kanagaratnam, P.: Changes in the Velocity Structure of the Greenland Ice Sheet, Science, 311, 986-990, 2006.

Rignot, E., Koppes, M., and Velicogna, I.: Rapid submarine melting of the calving faces of West Greenland glaciers, Nature Geosci., 3, 765, 2010.

Seale, A., Christofferson, P., Mugford, R. I., and O'Leary, M.: Ocean forcing of the Greenland Ice Sheet: Calving fronts and patterns of retreat identified by automatic satellite monitoring of eastern outlet glaciers, J. Geophys. Res., 116, F03013, doi:10.1029/2010JF001847, 2011.
Straneo, F., Hamilton, G., Sutherland, D., Stearns, L., Davidson, F., Hammill, M., Stenson, G., and Rosing-Asvid, A.: Rapid circulation of warm subtropical waters in a major glacial fjord in East Greenland, Nature Geosci., 3, 764, 2010.

Tapley, B., Bettadpur, S., Watkins, M., and Reigber, C.: The gravity recovery and climate experiment: Mission overview and early results, Geophys. Res. Lett., 31, L09607, doi:10.1029/2004GL019920, 2004.

Thierry, V., de Boisséson, E., and Mercier, H.: Interannual variability of the Subpolar Mode Water properties over the Reykjanes Ridge during 1990-2006, J. Geophys. Res., 113, C04016, doi:10.1029/2007JC004443, 2008.

Thomas, R., Frederick, E., Krabill, W., Manizade, S., and Martin, C.: Progressive increase in ice loss from Greenland, Geophys. Res. Lett., 33, L10503, doi:10.1029/.2006GL026075, 2006.

van den Broeke, M., Bamber, J., Ettema, J., Rignot, E., Schrama, E., van de Berg, W., van Meijgaard, E., Velicogna, I., and Wouters, B.: Partitioning Recent Greenland Mass Loss, Science, 326, 984-986, 2009.

Velicogna, I.: Increasing rates of ice mass loss from the Greenland and Antarctic ice sheets revealed by GRACE, Geophys. Res. Lett., 36, L19503, doi:10.1029/2009GL040222, 2009.

Velicogna, I. and Wahr, J.: Acceleration of Greenland ice mass loss in spring 2004, Nature, 443, 329-331, 2006.

Weidick, A.: Surging glaciers in Greenland: a status, Grønl. Geol. Undersøgelse, Rapp., 140, 106-110, 1988.

Zwally, H. J., Li, J., Brenner, A. C., Beckley, M., Cornejo, H. G., DiMarzio, J., Giovinetto, M. B., Neumann, T. A., Robbins, J., Saba, J. L., Yi, D., and Wang, W.:, Greenland ice sheet mass balance: distribution of increased mass loss with climate warming; 2003-07 versus 1992-2002, J. Glaciol., 57, 88-102, 2011. 